Research Association of British Flour Millers. Pending the appointment of a successor to Sir Jack Drummond, Dr. M. Pyke, who has returned to the Ministry's service from the Control Commission for Austria, will take charge of nutritional matters, and Dr. H. R. Barnell will deal with technological problems in regard to particular commodities.

\section{British Association: Forthcoming Meetings}

THE British Association will hold its annual meeting and two conferences during July. As the Association has no meeting-rooms of its own, various societies have generously granted the use of their premises for these occasions. At the annual meeting, to be held in the hall of the British Medical Association on July 20, the president, Sir Richard Gregory, will deliver his address on "Civilization and the Pursuit of Knowledge". Empire and foreign scientific delegates will be entertained at luncheon, and there will be a soirée in the rooms of the Geological Society. On the following day, July 21, the Association will hold an afternoon reception at Down House, which has already been re-opened to the public since the War. On July 8 , a conference will take place in the theatre of the Royal Institution, on the "Dissemination of Scientific Information to the Public, through the Press, Broadcasting, Films, Museums and Exhibits". This conference will be held by the Association in collaboration with the Royal Society and the Empire Scientific Conference. Sir Henry Dale will preside. On July 25, the Association is arranging a conference to discuss the relation of the United Nations Educational, Scientific and Cultural Organisation to the universities, to be held at the Royal Institute of British Architects. There will be sessions on the intra-mural and extra-mural work of universities, and on their international relations. Among the speakers will be Sir Richard Gregory, Sir Alfred Zimmern, Mrs. Layton, Miss Lynda Grier, Dr. Maxwell Garnett, Prof. Bonamy Dobrée, Mr. P. R. Morris and Dr. Julian Huxley.

While this year's annual meeting of the British Association will be exceptional in being held in London on one day only, the pre-war practice of meetings lasting a week and held in provincial centres will be resumed in future. The meeting in 1947 will take place in Dundee, where the meeting in 1939 was cut short by the imminence of war. In 1948 the Association will meet in Brighton.

\section{Handbooks of the British Fauna and Flora}

A CONFErence convened by the Association for the Study of Systematics in Relation to General Biology was held in the rooms of the Linnean Society on May 30 to consider the present position regarding the production of handbooks on the British fauna and flora. Representatives of fifteen biological societies and organisations, whose programmes include this type of work, were present. In his opening remarks, Dr. W. B. Turrill pointed out that the matter had been under review by the Association before the War and that the way had been cleared by the publication of its "Bibliography of Key Works for the Identification of the British Fauna and Flora". There are many groups of animals of which there are neither monographs nor handbooks in existence, and it is most desirable that the existing gaps should be filled. The position with regard to plants is more satisfactory since, although some groups of crypto. gams have no monographs or handbooks and others need revision, the phanerogams are already adequately covered. Capt. C. Diver outlined the work already done and stated that a list, based on the "Key Works", has been prepared to show these gaps. A measure of co-ordination between interested publishing bodies is necessary to obtain some degree of uniformity in treatment and arrangement. Considerable discussion followed during which it became evident that there is a general desire for a complete new series forming a "Fauna et Flora Britannica". The difficulty of finding authors able and willing to write handbooks for certain groups was discussed, as well as the means of financing publication. By the general wish of the meeting, the Association was urged to prepare a scheme, including recommenda. tions regarding scope, format, groups most urgently needing attention and finance, for submission to a similar conference to decide on a line of action.

\section{Conference on Industrial Spectroscopy}

THE newly formed Industrial Spectroscopic Group of the Institute of Physics will hold its first conference during July 5-6 at the Wellcome Research Founda. tion, 183 Euston Road, London, N.W.1. The Conference will review the present status of industrial spectroscopy and will be open to all interested with out charge, whether members of the Institute or not. The meetings on July $5(2.30-7.0$ p.m.) will be devoted to infra-red absorption spectroscopy. The speakers will be Dr. H. W. Thompson, of St. John's College, Oxford, on the significance of absorption spectroscopy for analytical purposes, and Mr. G. F. Lothian, of the South-West Essex Technical College, on equipment for infra-red absorption measurements. The meetings on July 6 (10.0 a.m. -5.0 p.m.) will deal only with emission spectroscopy. Mr. Nickelson, of Woolwich Arsenal, will discuss equipment for spectrographic analysis; Mr. A. Walsh, of the British Non-Ferrous Metals Research Association, will speak on spectroscopic light-sources for the analysis of metals and alloys; Mr. H. T. Shirley, of the Brown-Firth Research Laboratories, on a statistical examination of sources of error in the spectrographic analysis of alloy steel.

\section{Exhibition of Early Medical Manuscripts and Books at Edinburgh}

A SELECTION of books and manuscripts, to illustrate a series of lectures by Dr. Douglas Guthrie on the history of medicine, has been placed on view in the Upper Library Hall of the University of Edinburgh. Included among manuscripts of the thirteenth century are beautifully written copies of the "Breviarium Medicum" of Serapion, a Syrian physician of the ninth century, and of Avicenna's "Canon of Medicine", a favourite text-book, by the "Prince of Arabian Physicians", which retained its popularity for many centuries and is said to be used still by native practitioners in India. There is also a fifteenth century manuscript of the "Regimen of Health of Salerno", the best-known work of that famous school of medicine. It contains a full-page illustration of a medieval physician and one of his patients. A modern manuscript of much interest, on loan from the Royal College of Surgeons of Edinburgh, is a volume of notes of lectures on surgery, delivered by Lister while he was at Glasgow, containing the first written account of his "antiseptic principle". Among the printed books the greatest rarity is "Christianismi Restitutio", published in 1553 by Michael Servetus, 